\title{
Adenosquamous Carcinoma of the Ampulla of Vater: A Rare Cause of Obstructive Jaundice
}

\author{
Liliana Carvalho Maria Ana Túlio Joana Carmo Miguel Bispo
}

\section{Cristina Chagas}

Gastroenterology Department, Hospital Egas Moniz, Centro Hospitalar de Lisboa Ocidental, Lisbon, Portugal

\section{Keywords}

Jaundice · Endoscopic ultrasonography · Ampullary tumor · Adenosquamous carcinoma

\section{Carcinoma Adenoescamoso da Ampola de Vater: Uma Causa Rara de Icterícia Obstrutiva}

\section{Palavras Chave}

Icterícia · Ultrassonografia endoscópica - Ampuloma . Adenocarcinoma escamoso

A 68-year-old Caucasian male was admitted with painless jaundice, choluria, and acholia for the previous 10 days. On admission, the patient was markedly affected by jaundice, with no relevant findings in the abdominal examination. Laboratory tests showed conjugated hyperbilirubinemia (total $15.4 \mathrm{mg} / \mathrm{dL}$; conjugated $10.7 \mathrm{mg} / \mathrm{dL}$ ), elevated transaminase levels (ALT $271 \mathrm{U} / \mathrm{L}$; AST 102 $\mathrm{U} / \mathrm{L}$ ), and cholestasis parameters (GGT 1,049 U/L; AP $279 \mathrm{U} / \mathrm{L})$. Abdominal ultrasonography revealed dilation of the common bile duct and intrahepatic biliary ducts.

\section{KARGER}

E-Mail karger@karger.com www.karger.com/pjg
(C) 2017 Sociedade Portuguesa de Gastrenterologia Published by S. Karger AG, Basel

Karger

Open access

This article is licensed under the Creative Commons AttributionNonCommercial-NoDerivatives 4.0 International License (CC BYNC-ND) (http://www.karger.com/Services/OpenAccessLicense) Usage and distribution for commercial purposes as well as any distribution of modified material requires written permission.
Tumour markers CA19.9 and CEA were normal. Endoscopic ultrasound was performed using a linear scope and showed a subepithelial mass of the papilla (Fig. 1), corresponding to a hypoechogenic lesion of $22 \mathrm{~mm}$, with submucosal growth, involving the muscularis propria of the duodenum (T2) (Fig. 2). This lesion caused marked dilation of the proximal common bile duct and intrahepatic ducts. A perilesional adenopathy was identified (N1). Endoscopic ultrasound-guided fine needle aspiration (EUSFNA) was performed using a 25-gauge needle and cytologic evaluation was consistent with adenocarcinoma. Computed tomography ruled out distant metastasis and the patient was referred for surgery (cephalic duodenopancreatectomy). Histological analysis of the surgical specimen documented an adenosquamous carcinoma of the ampulla of Vater (ASC AV; Fig. 3), involving the duodenal muscularis propria, with one regional lymph node metastasis (R0, pT2N1). Postoperative outcome was uneventful and the patient remains asymptomatic after a 10-month follow-up period.

Adenocarcinomas account for most primary malignant tumors of the ampulla of Vater, while other histological types such as squamous or adenosquamous carcinomas are exceedingly rare [1]. Duodenoscopy in combi- 


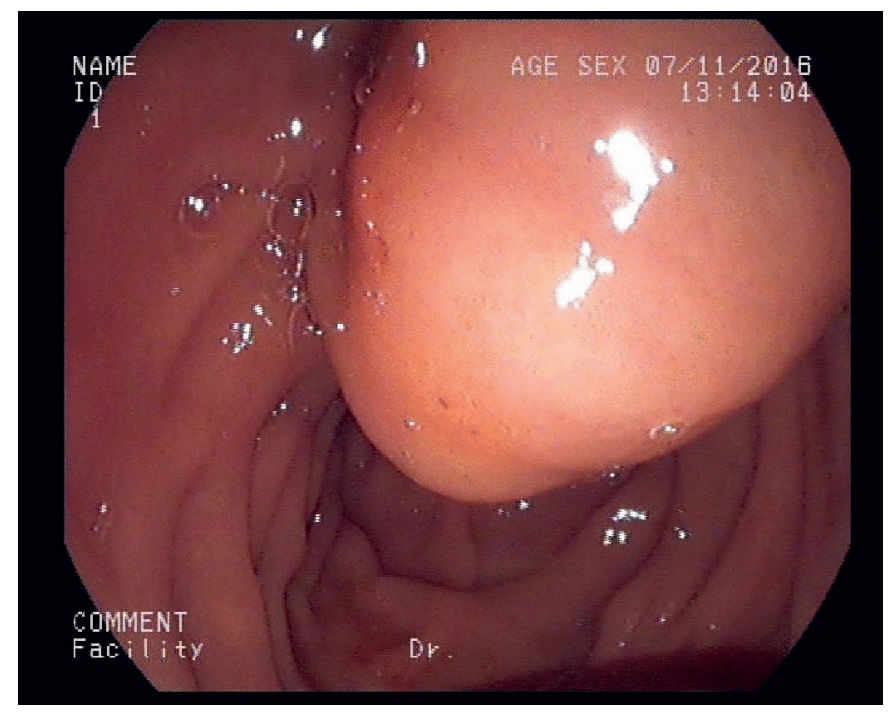

Fig. 1. Subepithelial mass of the papilla.

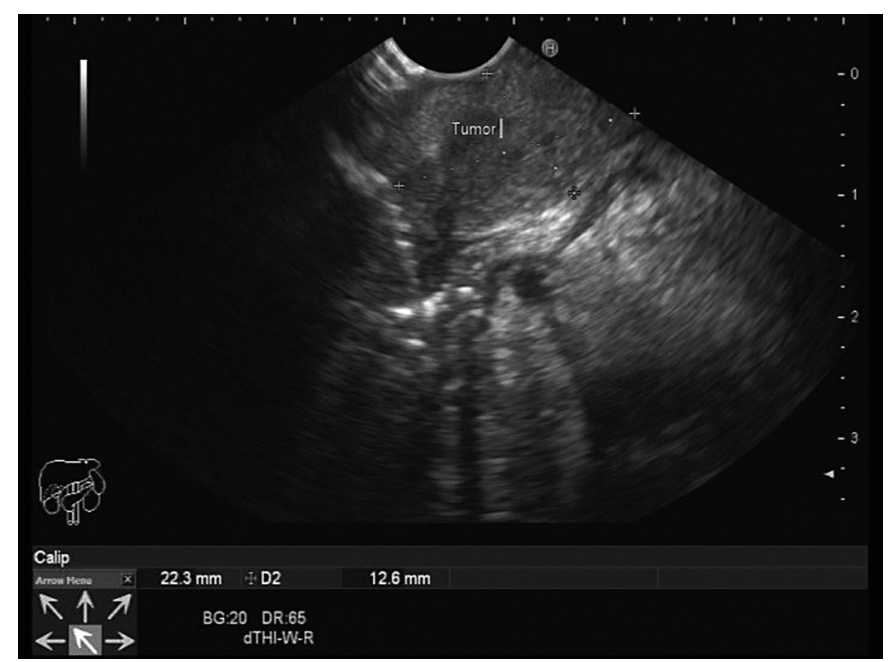

Fig. 2. Hypoechogenic lesion of $22 \mathrm{~mm}$, with submucosal growth, involving the muscularis propria of the duodenum (T2).

nation with EUS-FNA are first-line diagnostic procedures in the workup of papillary tumors. Surgery is the treatment of choice in the presence of invasive carcinoma (T>T1a; N1) [2].

ASC AV is an extremely rare condition, with scarce case reports in the literature. It is defined as a tumor in which both glandular and squamous components are malignant, being clinically more aggressive, with worse prognosis than conventional adenocarcinoma [3]. The

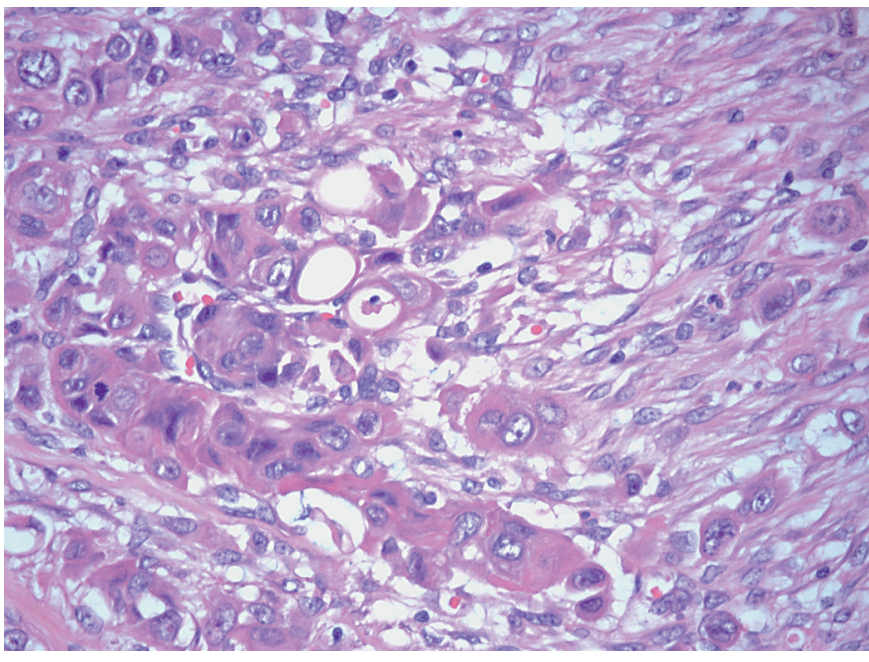

Fig. 3. Poorly differentiated carcinoma showing pleomorphic cells with dense eosinophilic cytoplasm suggestive of squamous differentiation.

origin of squamous carcinoma in the ampulla of Vater remains unclear. Squamous metaplasia of the pancreatic ductal epithelium after chronic inflammation has been hypothesized as one of the possible oncogenic mechanisms [4].

The clinicopathological features and biologic behavior of ASC AV are largely unknown because of the rarity of this condition. Outcomes of this entity remain unclear and no therapeutic strategies have been established.

In a review of 7 cases of ASC AV, the mean age at diagnosis was 62 years and $71 \%$ were men. In 4 cases, the squamous components were identified in preoperative endoscopic biopsy results, whereas the diagnosis of adenosquamous carcinoma was made after surgical resection in 3 cases. Overall survival in all 7 cases ranged from 6 to 20 months [5].

\section{Disclosure Statement}

The authors have no conflicts of interest to declare.

\section{Statement of Ethics}

This report has been performed in accordance to the principles of the Helsinki Declaration, in order to protect patient confidentiality. 


\section{References}

1 Saavedra-Albores J, Hruban RH, Klimstra DS, Zamboni G: Invasive adenocarcinoma of the ampullary region. In: Bosman F, Carneiro F, Hruban H, Theise D (eds): WHO Classification of Tumours of the Digestive System, ed 4. Lyon, International Agency for Research on Cancer, 2010, pp 87-90.
2 Napoléon B: Écho-endoscopie biliaire; in Palazzo L (ed): Écho-Endoscopie Digestive. France, Springer-Verlag, 2012, pp 219-227.

3 Yang S-J, Ooyang C-H, Wang S-Y, et al: Adenosquamous carcinoma of the ampulla of Vater - a rare disease at unusual location. World J Surg Oncol 2013;11:124.
4 Balci B, Calik B, Karadeniz T, Sahin H, Ugurlu L, Aydin C: Primary squamous cell carcinoma of the ampulla of Vater: a case report. Surg Case Rep 2016;2:2.

5 Hoshimoto S, Aiura K, Shito M, Kakefuda T, Sugiura H: Adenosquamous carcinoma of the ampulla of Vater: a case report and literature review. World J Surg Oncol 2015;13:287. 